\title{
Commodity Futures Returns: A Non Linear Markov Regime Switching Model of Hedging and Speculative Pressures
}

\author{
Giulio Cifarelli* and Giovanna Paladino ${ }^{\circ}$
}

\section{Abstract}

This study introduces a non linear model for commodity futures prices which accounts for the pressures due to hedging and speculative activities. The interaction with the corresponding spot market is considered assuming that a long term equilibrium relationship holds between futures and spot pricing. Over the 1990-2010 time period, a dynamic interaction between spot and futures returns in five commodity markets (copper, cotton, oil, silver, and soybeans) is empirically validated. An error correction relationship for the cash returns and a non linear parameterization of the corresponding futures returns are combined with a bivariate CCC-GARCH representation of the conditional variances.

Hedgers and speculators are contemporaneously at work in the futures markets, the role of the latter being far from negligible. Finally, in order to capture the consequences of the growing impact of financial flows on commodity market pricing, a two-state regime switching model for futures returns is developed. The empirical findings indicate that hedging and speculative behavior change significantly across the two regimes, which we associate with low and high return volatility. High volatility regimes are, as expected, characterized by a stronger impact of speculation on futures return dynamics.

Keywords: Commodity spot and futures markets, dynamic hedging, speculation, non linear GARCH, Markov regime switching.

\section{JEL Classification G13, G15, Q47}

The authors are grateful to Filippo Cesarano for extremely useful suggestions. The usual disclaimer applies.

\footnotetext{
* University of Florence. Dipartimento di Scienze Economiche, via delle Pandette 9, 50127, Florence Italy; g.cifarelli.76@cantab.net

- LUISS University Economics Department and IntesaSanpaolo, Piazza San Carlo 156, 10156 Torino Italy; gpaladino@luiss.it or giovanna.paladino@intesasanpaolo.com
} 


\section{Introduction}

A position in a commodity futures market is based on expectations about the future price behavior and profits (or losses) depend on the accuracy of the latter. Commodity futures trading does not usually contemplate the physical delivery upon expiration of the contract. Indeed, offsetting the position by selling (or buying) back the futures contract is not only doable but a cheaper strategy.

In this paper we will focus on the two main activities associated with futures trading: hedging and speculation. They do not have to be considered as referring to two separate agents. It may well be that typical hedgers, such as commercial firms, take a view on the market (speculate on price direction). Alternatively, speculators can find it profitable to engage in hedging activities (see Stulz, 1996, and Irwin et al., 2009). Consequently it could be misleading to consider hedgers as pure riskaverse agents and speculators as risk-seekers. The futures' demand functions used in this paper will avoid this simplistic divide.

Futures trading involves an exchange between people with opposite views of the market (as to the future behavior of prices) and/or a different degree of risk aversion. It allows to shift the risk from a party that desires less risk to a party that is willing to accept it in exchange for an expected profit. $^{1}$

Why hedging with futures? Futures trading started - historically - when commodity producers and consumers tried to offset the losses due to unfavorable price fluctuations. Indeed, the main purpose of hedging is to reduce the price risk. In the case of an expected price decline, the hedging strategy of a producer will be to sell a futures contract at time $t$ and to buy it back at expiration at time $t+n$. Assuming for simplicity that $F_{t}=C_{t}$ where $F_{t}$ is the futures price and $C_{t}$ is the corresponding cash price of a given commodity, the producer will earn the difference $F_{t}-C_{t+n}>0$. (The futures price converges to the spot price at the expiry and $F_{t+n} \equiv C_{t+n}$.) In the case of an expected price increase, the hedging

1 Fagan and Gencay (2008) find that hedgers and speculators are often counterparties, since they tend to take opposing positions. Their respective long positions exhibit a strong negative correlation. 
strategy for a consumer will be to buy a futures contract (with maturity at time $\mathrm{t}+\mathrm{n}$ ) at time $\mathrm{t}$ at price $F_{t}=C_{t}$ and sell it at time $\mathrm{t}+\mathrm{n}$. He will obtain the difference $C_{t+n}-F_{t}>0$ that will cover the loss due to the increase in the spot price from $C_{t}$ to $C_{t+n}$. In general futures and cash prices at time $t$ do not coincide. The difference is known as basis and can be either positive or negative. It is usually considered an estimate of storage costs, transportation costs, and profit margins for sellers, but it could also reflect the local supply and demand conditions. When $F_{t}<C_{t}$ (contango) then the market is dominated by risk averse commodity producers willing to pay a premium for their price insurance. On the contrary, when $F_{t}>C_{t}$ (normal backwardation) the futures market is dominated by risk averse commodity consumers.

Speculation is essential for the smooth functioning of commodity markets as it assures liquidity and assumes the risks laid off by the hedgers. Speculators, mainly non commercial firms or private investors, are ready to take up risks in order to earn profits stemming from expected price changes. No physical delivery is involved in this futures trade and speculation does not intervene directly in the cash market.

The literature has studied hedging and speculation in commodity futures from very different perspectives.

In the sixties optimal hedging behavior was identified by Johnson (1960), Stein (1961), and McKinnon (1967). They associated it with the minimization of the variance of the return of the portfolio of an hedger, constructed with cash and futures contracts. This approach allows to compute an optimal cover ratio $\beta$ (the Minimum Variance Hedge ratio), defined as the percentage of cash contracts matched by futures positions that minimizes the variance of the hedged portfolio. It owes its popularity to its simplicity, since $\beta$ - given by the ratio between the covariance of cash and futures returns and the variance of futures returns - can be easily estimated.

This approach has been refined both from a theoretical point of view - by introducing a larger spectrum of objective functions to be optimized - and from an empirical standpoint - by utilizing more complex econometric 
methods that allow for time series heteroskedasticity and time variation of the hedge ratio.

The MVH strategy focuses on the variance of the hedged portfolio and pays no attention to its expected return. Subsequent improvements include strategies based on hedged portfolio return mean and variance expected utility maximization ${ }^{2}$ (Cecchetti et al., 1988, Lence, 1995), minimization of the extended mean-Gini coefficient (Kolb and Okunev, 1992), or based on the Generalised Semivariance (GSV) (Lien and Tse, 2000). It has been shown, however, that if futures prices are martingale processes and if the spot and futures returns are jointly normal then the optimal hedge ratio will converge to the ratio obtained with the MVH strategy. As for commodity futures, Chen et al. (2008) find that it is not possible to reject the pure martingale hypothesis while the joint normality holds only selectively and over long horizons.

The correlation between spot and futures is not perfect and, given the stochastic nature of futures and spot prices, the hedge ratio is unlikely to be constant. Static OLS hedge ratio estimation recognizes that the correlation between the futures and spot prices is less than perfect (Ederington, 1979, Figlewski, 1984), but imposes the restriction of a constant correlation between spot and futures price rates of changes. As such it could lead to sub-optimal hedging decisions in periods of high basis volatility and/or to inefficient revisions of the hedge ratio.

Recently, a large body of literature has arisen to cope with the dynamics of the joint distribution of the returns and with the time-varying nature of the optimal hedge ratio, using the large family of $\mathrm{GARCH}$ models. These studies suggest that optimal hedge ratios are time dependent and that dynamic hedging reduces in-sample portfolio variance substantially more than static hedging.

The out-of-sample advantages of the GARCH hedge ratio are much more controversial. Some argue that the GARCH hedge ratio enhances the outof-sample hedging effectiveness (see, among others, the seminal works of Baillie and Myers, 1991, and of Kroner and Sultan, 1993, Lee and Yoder,

\footnotetext{
2 The MVH is not only compatible with a quadratic utility function but, as shown by Benninga et al. (1983), under certain conditions, it is consistent with expected utility maximization, a result that does not depend upon the nature of the utility function.
} 
2007, who implement a Markov switching GARCH, and Chan and Young, 2006, who incorporate a jump component in a bivariate GARCH). Others, however, considering the trade off between the benefits of a dynamic hedge and both the complexity of the implementation of the GARCH method and the costs of portfolio rebalancing, conclude that static hedging is to be preferred (Lence, 1995, Miffre, 2004, and Alexander and Barbosa, 2007). Recent mixed evidence is set forth by Park and Jei (2010), while Lien (2009) finds that GARCH modeling raises hedging effectiveness mostly in small samples, when there are sufficiently large fluctuations in the conditional variance of the futures returns.

The literature on commodity market speculation has followed two main strands. A direct approach based on an attempt to micro model simultaneously speculative and hedging behavior and an indirect approach, which analyzes the excess co-movement of commodity prices (with respect to common fundamentals) and ascribes this evidence to 'herding' behavior. In addition some recent studies have tried to exploit the information, extrapolated from the data provided by the CFTC, on the commitments of traders.

In an important paper Johnson (1960) suggests that hedging and speculation in the futures markets are interrelated. Speculation is mainly attributed to traders' expectations on future price changes that bring about an increase/decrease of the optimal hedging ratio in a short hedging context. Ward and Fletcher (1971) generalize Johnson's approach to both long and short hedging and find that speculation is associated with optimal futures positions (short or long) that are in excess of the 100 percent hedging level.

A different strand of analysis on speculation in the commodity markets focuses on the presence of excess (with respect to a component explained by fundamentals) co-movement of returns of unrelated commodities (Pyndick and Rotemberg, 1990). Subsequent research - see among others Cashin et al. (1999), Ai et al. (2006), and Lescaroux (2009) - challenged the excess co-movement hypothesis on both empirical and methodological grounds. The overall results are mixed and could indeed depend on the selection of the estimation techniques and/or of the information set (Le Pen and Sevi, 2010). 
In recent year the availability of data on the Commitments of Traders Reports, provided by the Commodity Futures Trading Commission, has generated a body of papers that try to assess the impact of speculation on commodity prices measuring speculative positions in terms open interest. The weekly open interest of each commodity is broken down, according to the purposes of traders, in long and short reporting commercial hedging, long and short speculation by reporting non commercial firms, and positions of non reporting traders. The empirical results, however, are mixed (Fagan and Gencay, 2008).

This paper contributes to the current debate in different ways.

a. Using a complex non linear CCC-GARCH approach we model explicitly the reaction of hedgers and speculators to volatility shifts in the commodity markets. In this way the literature is extended by adding a dynamic component to the standard two-step optimal hedge ratio computation.

b. A two-state Markov switching procedure is used to model the impact of changes in the behavior of commodity markets, changes due to bullish/bearish reactions to futures price changes and/or to shifts in risk aversion brought about by return volatility changes. We identify in this way a financial pattern that seems to play a growing role in recent commodity market pricing.

c. We model and assess empirically the relative impact of speculative vs. hedging drivers on futures pricing, and show that periods of high futures return volatility are usually to be associated with a more intense speculative activity.

\section{Section 1 The model}

Commodity future trading is analyzed in this section, focusing on hedging and speculative behavior. A hedging transaction is intended to reduce the risk of unwanted future cash price changes to an acceptable level. Spot market trades are then associated with trades of the opposite sign in the corresponding futures market. If the current cash and futures prices are positively correlated, the financial loss in one market will be compensated 
by the earnings obtained from holding the opposite position in the other market.

In more detail, let $r_{c, t}^{i}=\Delta \log C_{t}^{i}$ and $r_{f, t}^{i}=\Delta \log F_{t}^{i}$, where $C_{t}^{i}$ is the cash (spot) price of commodity $i$ and $F_{t}^{i}$ is the price of the corresponding futures contract. An investor who takes a long (short) position of one unit in the cash market $i$ will hedge by taking a short (long) position of $\beta$ units in the corresponding futures market, which he will buy (sell) back when he sells (buys) the cash. The hedge ratio $\beta$ can be seen as the proportion of the long (short) cash position that is covered by futures sales (purchases). ${ }^{3}$

The revenue of this hedging position (or portfolio), i.e. the hedger's return $r_{H, t}^{i}$, is given by

$$
r_{H, t}^{i}=r_{c, t}^{i}-\beta r_{f, t}^{i}
$$

The variance of this portfolio is given by

$$
\sigma_{r_{H}^{i}, t}^{2}=\sigma_{r_{c}^{i}, t}^{2}+\beta^{2} \sigma_{r_{f}^{i}, t}^{2}-2 \beta \sigma_{r_{c}^{i}, t} \sigma_{r_{f}^{i}, t} \rho_{r_{c}^{i} r_{f}^{i}, t}
$$

where $\sigma_{r_{c}^{i}, t}^{2}$ is the variance of $r_{c, t}^{i}, \sigma_{r_{f}^{i}, t}^{2}$ is the variance of $r_{f, t}^{i}$, and $\rho_{r_{c}^{i} r_{f}^{i}, t}$ is the correlation between $r_{c, t}^{i}$ and $r_{f, t}^{i}$.

The optimum hedge ratio $\beta *$ is derived from the first order condition of the hedging portfolio variance minimization and reads as (from now on we drop the superscript $i$ ):

$$
\beta *=\frac{\sigma_{r_{c}, t} \sigma_{r_{f}, t} \rho_{r_{c} r_{f}, t}}{\sigma_{r_{f}, t}^{2}}
$$

\footnotetext{
3 The hedge ratio is also defined as the ratio between the number of futures and cash contracts.
} 
The optimum hedge ratio depends upon both the covariance between the changes in futures and cash prices and the variance of the futures price changes.

In the empirical analysis below we will assess the effectiveness of the optimum hedge ratio using as benchmarks the unhedged cash position (when $\beta=0)$, and the naïve hedge portfolio $(\beta=1)$, where the futures position is opposite in sign but of equal magnitude to the cash position.

In order to analyze the reaction of hedgers to shifts in commodity returns, we extend the standard hedging model by introducing a dynamic component.

We assume that the expected utility of hedgers is an inverse function of the expected variability of their optimally hedged position. The variance of this position (or portfolio) can be defined, replacing in equation (2) the optimal hedge ratio $\beta *$ by its determinants set out in equation (3), as

$$
\begin{aligned}
& \sigma_{r_{H}, t}^{2 * *}=\sigma_{r_{c}, t}^{2}-\frac{\left(\sigma_{r_{c} r_{f, t}}\right)^{2}}{\sigma_{r_{f, t}}^{2}}=\sigma_{r_{c}, t}^{2}\left(1-\rho_{r_{c} r_{f}, t}^{2}\right) \\
& \text { where } \rho_{r_{c} r_{f}, t}^{2}=\sigma_{r_{c} r_{f}, t}^{2} / \sigma_{r_{f}, t} \sigma_{r_{c}, t}
\end{aligned}
$$

The demand of futures contracts of an hedger wishing to minimize the variance of his optimal portfolio is defined as

$$
D_{t}^{H}=a_{0}+b^{H} \sigma_{r_{c}, t}^{2}\left(1-\rho_{r_{c} r_{f}, t}^{2}\right)
$$

An increase in the minimum portfolio variance may be due to a rise in the variability of cash price changes and/or to a decrease in the correlation between cash and futures price changes. We can thus reasonably assume that $b^{H}$ is positive if consumers' hedging is prevailing since consumers, concerned about cash price increases, will demand more futures contracts whenever the portfolio variance increases. Conversely, $b^{H}$ will be negative if producers' hedging is prevailing, since producers, worried about possible 
cash price decreases, will supply more (i.e. demand less) contracts if the variability of their hedged position rises.

The demand for futures contracts of a speculator is defined as

$$
D_{t}^{S}=c_{0}+d^{S} E_{t-1} r_{f, t}-e^{S} \sigma_{r_{f}, t}^{2}
$$

$d^{S}$ is always positive because of the positive impact on speculation of an increase in expected futures returns, whereas $e^{S}$ can be either positive or negative, according to the reaction of speculators to risk. We assume that $e^{S}<0$ for risk lover and $e^{S}>0$ for risk averse agents.

It is generally accepted that futures trading is a zero sum game. As pointed out by Hieronymus (1977), among others, "for everyone who thinks the price is going up there is someone who thinks it is going down, and for everyone who trades with the flow of the market, there is someone trading against it"(pg 302). Thus we can assume that the net demands of both agents are balanced or equivalently that the demands of hedgers and speculators add up to 1 , i.e. that

$$
D_{t}^{H}+D_{t}^{S}=1
$$

Substituting equations (4) and (5) in equation (6) and readjusting terms, we obtain the following expression for the expected futures return

$$
E_{t-1} r_{f, t}=\frac{1}{d^{S}}\left(1-a_{0}-c_{0}-b^{H} \sigma_{r_{c}, t}^{2}\left(1-\rho_{r_{c} r_{f}, t}^{2}\right)+e^{S} \sigma_{r_{f}, t}^{2}\right)
$$

Since $r_{f, t}=E_{t-1} r_{f, t}+u_{r_{f}, t}$, we obtain the following testable relationship

$$
r_{f, t}=C-\left(b^{H} / d^{S}\right) \sigma_{r_{c}, t}^{2}\left(1-\rho_{r_{c} r_{f}, t}^{2}\right)+\left(e^{S} / d^{S}\right) \sigma_{r_{f}, t}^{2}+u_{r_{f}, t}
$$

where $C=\left(1-a_{0}-c_{0}\right) / d^{S}$. Equation (8) relates futures returns to their own volatility and to the variability of the optimally hedged portfolio. The 
absolute value of the ratio $e^{S} \sigma_{r_{f}, t}^{2} / b^{H} \sigma_{r_{c}, t}^{2}\left(1-\rho_{r_{c} r_{f}, t}^{2}\right)$ measures the relative impact of speculation on futures returns the so-called "level of importance". 4

The dynamics of this relationship is in line with the stylized facts detected in a paper by Fagan and Gencay (2008), where the negative correlation between futures returns and hedger net long positions supports the idea that large speculators are net buyers in rising markets, while large hedgers are net sellers. This behavior is encompassed by our (more general) model, when it contemplates the case of hedgers being net sellers - when $b^{H}$ is negative - and futures returns going up.

\section{Section 2 A bivariate non linear CCC-GARCH representation}

We focus on futures prices since commodity prices are typically discovered in futures markets and price changes are passed from futures to cash markets (Garbade and Silber, 1983). Indeed, trading is quicker and cheaper in the futures than in the cash markets. Economic theory, however, suggests that the prices of the cash assets and of the corresponding futures contracts are jointly determined (Stein, 1961). Our empirical estimation thus includes a relationship that describes the behavior of cash returns, along a futures returns relationship, and analyzes the covariance between these two variables. Over the longer term equilibrium prices are ultimately determined in the cash market as all commodity futures prices at delivery date converge to the cash price (plus or minus a constant). This behavior justifies the existence of a cointegration relationship between futures and cash prices and the use of an error correction parameterization of the (conditional) mean equation for $r_{c, t}$.

In order to investigate empirically the presence of hedging and speculation in the commodity markets we estimate a non linear bivariate GARCH model for futures and spot returns. The conditional mean of the futures returns is modeled by equation $\left(9^{\prime}\right)$, the conditional mean of the

\footnotetext{
${ }^{4}$ Achen (1982, pg 72-73).
} 
cash returns, equation (9), is parameterized by an autoregressive error correction structure, and the conditional second moments are quantified by a bivariate CCC-GARCH $(1,1)$.

$$
\begin{aligned}
& r_{c, t}=a_{0}+\sum_{j=1}^{n} a_{j} r_{c, t-j}+a_{n+1} r_{f, t-1}+\varepsilon_{1}\left(f_{t-1}-d_{0}-d_{1} c_{t-1}\right)+u_{r_{c}, t} \\
& r_{f, t}=e_{0}-\left(b^{H} / d^{S}\right)\left(h_{r_{c}, t}^{2}-h_{r_{c} r_{f}, t}^{2} / h_{r_{f}, t}^{2}\right)+\left(e^{S} / d^{S}\right) h_{r_{f}, t}^{2}+u_{r_{f}, t} \\
& u_{t}=\left[\begin{array}{l}
u_{r_{c}, t} \\
u_{r_{f}, t}
\end{array}\right] \\
& u_{t} \mid \Omega_{t-1} N\left(0, H_{t}\right)
\end{aligned}
$$$$
H_{t}=\Delta_{t} R \Delta_{t}
$$$$
R=\left[\begin{array}{cc}
1 & \rho_{r_{c} r_{f}} \\
\rho_{r_{c} r_{f}} & 1
\end{array}\right] \quad \Delta_{t}=\left[\begin{array}{cc}
h_{r_{c}, t} & 0 \\
0 & h_{r_{f}, t}
\end{array}\right]
$$$$
h_{r_{c}, t}^{2}=\varpi_{c}+\alpha_{c} h_{r_{c}, t-1}^{2}+\beta_{c} u_{r_{c}, t-1}^{2} ; \quad h_{r_{f}, t}^{2}=\varpi_{f}+\alpha_{f} h_{r_{f}, t-1}^{2}+\beta_{f} u_{r_{f}, t-1}^{2}
$$

\section{Section 3 The empirical behavior of five commodity markets}

Our daily data span the 3 January 1990 - 26 January 2010 time period. All the contracts are traded on the NYMEX (New York Mercantile Exchange) and are taken from Datastream. Both spot $\left(C_{t}\right)$ and futures prices $\left(F_{t}\right)$ are expressed in US dollars. Futures prices correspond to the highly liquid 1 month (nearest to delivery) futures contract. ${ }^{5}$ Returns are computed as first differences of the logarithms of the price levels. The model is tested for 5 commodities belonging to different commodity sectors: cotton (industrial materials), copper (industrial metals), crude oil (energy), silver (precious metals), and soybeans (grains).

Summary statistics of cash and futures returns are presented in Table 1.

$<$ INSERT TABLE 1 ABOUT HERE >

\footnotetext{
${ }^{5}$ The futures contract expires on the 3rd business day prior to the 25th calendar day of the month preceding the delivery month. If the 25th calendar day of the month is a nonbusiness day, trading ceases on the third business day prior to the business day preceding the 25th calendar day.
} 
Average daily returns are small but not negligible, higher for oil and lower for soybeans, a pattern that holds also for the daily standard deviations. ${ }^{6}$ The distributions of both cash and futures returns are always mildly skewed and significantly leptokurtic, the departure from normality being confirmed by the size of the corresponding Jarque Bera (JB) test statistics. Volatility clustering is detected in all cases a finding which supports the choice of a GARCH parameterization of the conditional second moments.

Tables 2 to 6 present parsimonious estimates of the equations of the bivariate non linear CCC-GARCH(1,1) system set forth in section 2 for 5 commodities. The overall quality of fit is satisfactory. The estimated parameters are significantly different from zero and the conditional heteroskedasticity of the residuals has been captured by our GARCH parameterization. ${ }^{7}$ The usual misspecification tests suggest that the standardized residuals $v_{t}$ are always well behaved; for each system $E\left[v_{t}\right]=0, E\left[v_{t t}^{2}\right]=1$, and $v_{t}^{2}$ is serially uncorrelated.

< INSERT TABLE 2 ABOUT HERE >

< INSERT TABLE 3 ABOUT HERE >

< INSERT TABLE 4 ABOUT HERE >

$<$ INSERT TABLE 5 ABOUT HERE >

$<$ INSERT TABLE 6 ABOUT HERE >

The futures return mean equation $\left(9^{\prime}\right)$ provides the following useful information on the market drivers. (i) Coefficient $b^{H}$ estimates are negative in the case of cotton, copper and soybeans - reflecting the predominance of producers on the markets - and positive for the remaining commodities of the sample (oil and silver), because of the preponderance of consumers. This result is also in line with the effects of hedging pressure, where futures prices increase when hedgers trade short and decrease when hedgers are long. ${ }^{8}$

(ii) The absolute value of the ratio between speculative and hedging factors set forth in Table 7 measures the relative impact of risk on futures

\footnotetext{
6 The logarithms of the prices of the cash and futures contracts are always I(1) and their first differences $\mathrm{I}(0)$. The test statistics are not reported for lack of space.

7 The t-ratios reported in the tables are based on the robust quasi-maximum likelihood estimation procedure of Bollerslev and Wooldridge (1992).

${ }^{8}$ See Chang (1985) and Bessembinder (1992).
} 
returns. It is higher than 1 for the copper, oil and soybeans markets, where speculators seem to be more reactive to futures risk than hedgers. Speculators are risk averse (since the corresponding $e^{s}$ coefficient estimates are positive) in the oil and silver markets only, a finding that may be due to the size of the volatility shocks. This issue shall be further investigated in the next section as is affected by the futures pricing regime shifts. (iii) The estimates of coefficient $d^{s}$, which represents the component of speculators' demand that is associated with price expectations, are always positive and significant. They tend to be small, however, if compared with those of the coefficients of the corresponding futures returns volatilities. ${ }^{9}$

\section{< INSERT TABLE 7 ABOUT HERE >}

The dynamic specification of our model might introduce distortive effects in the estimation of the optimal hedge ratio $\beta$, that reduce its effectiveness. We have thus performed the standard comparison of its hedging performance with the performance of a naïve portfolio hedge ratio $(\beta=1)$ and of an OLS hedge ratio, obtained as the futures return coefficient estimate in a regression of cash returns on a constant and on futures returns. An artificial daily portfolio is introduced where an investor is assumed to buy (sell) one unit of the cash asset and to sell (buy) $\beta$ units of the corresponding futures contract. The unconditional portfolio return standard deviations are computed over the whole sample and are set forth in Table 8 for the three hedge ratio estimators. The naïve hedge portfolios are clearly outperformed by the optimal hedge portfolios, a finding that differs from the results obtained by Alexander and Barbosa (2007). Commodity markets, in spite of their growing financiarization, cannot compare, in terms of efficiency, with the major stock markets and optimal hedging remains an effective risk reduction technique. Our CCCGARCH model provides the minimum risk hedge in three out of five markets, a finding that corroborates the validity of its parameterization.

\footnotetext{
9 Equation (9') imposes coefficient restrictions that are justified by the model. We have estimated a reduced form version of our $\operatorname{CCC}-\operatorname{GARCH}(1,1)$ model, replacing $\left(b^{H} / d^{S}\right)$ and $\left(e^{S} / d^{S}\right)$ with the corresponding unrestricted coefficients. We were unable to reject the null associated with these restrictions performing standard LR tests. The corresponding tests statistics are available from the authors upon request.
} 
Only in the case of cotton and soybeans, among the less volatile markets of the sample, does the OLS optimal hedge provide the best results. ${ }^{10}$

\section{$<$ INSERT TABLE 8 ABOUT HERE >}

\section{Hedging, speculation, and futures pricing regime shifts}

Sarno and Valente (2000) and Alizedeh and Nomikos (2004) analyzed the changes in the relationship between futures and spot stock index returns using a Markov switching model set out originally by Hamilton (1994). In our investigation we use this technique in order to analyze the shifts over two regimes in commodity market hedging and speculative behavior.

Using the full sample estimates of the conditional second moments obtained in the previous section, equation $\left(9^{\prime}\right)$ is adapted in a second step to a two-state Markov switching framework in which the drivers of futures returns are assumed to switch between two different processes, dictated by the state of the market.

Equation $\left(9^{\prime}\right)$ is thus rewritten as

$r_{f, t}=e_{0 s_{t}}-\left(b_{s_{t}}^{H} / d_{s_{t}}^{S}\right)\left(h_{r_{c}, t}^{2}-h_{r_{c} r_{f}, t}^{2} / h_{r_{f}, t}^{2}\right)+\left(e_{s_{t}}^{S} / d_{s_{t}}^{S}\right) h_{r_{f}, t}^{2}+u_{r_{f}, s_{t} t}$

where $u_{r_{f}, s_{t} t} \sim N\left(0, \sigma_{s_{t}}^{2}\right)$, and the unobserved random variable $s_{t}$ indicates the state in which is the market.

The value of the current regime $s_{t}$ is assumed to depend on the state of the previous period only, $s_{t-1}$, and the transition probability $P\left\{s_{t}=j \mid s_{t-1}=i\right\}=p_{i j}$ gives the probability that state $i$ will be followed by state $j$. In the two state case $p_{11}+p_{12}=1$ and $p_{22}+p_{21}=1$, and the corresponding transition matrix is

\footnotetext{
${ }^{10}$ If we repeat the exercise using weekly returns estimates of our CCC-GARCH $(1,1)$ model and introduce a weekly portfolio rebalancing, the CCC-GARCH beta portfolios consistently outperform both the OLS beta and naïve beta portfolios in all commodity markets.
} 
$P=\left[\begin{array}{cc}p_{11} & 1-p_{22} \\ 1-p_{11} & p_{22}\end{array}\right]$

The joint probability of $r_{f, t}$ and $s_{t}$ is then given by the product

$$
p\left(r_{f, t}, s_{t}=j \mid Y_{t-1}, \psi\right)=f\left(r_{f, t} \mid s_{t}=j ; Y_{t-1}, \psi\right) P\left(s_{t}=j \mid Y_{t-1}, \psi\right) \quad j=1,2
$$

where $Y_{t-1}$ is the information set that includes all past information on the population parameters and $\psi=\left(e_{0 s_{t}}, b_{s_{t}}^{H}, d_{s_{t}}^{S}, e_{s_{t}}^{S}, \sigma_{s_{t}}^{2}\right)$ is the vector of parameters to be estimated. $f\left(\right.$.) is the density of $r_{f, t}$, conditional on the random variable $s_{t}$, and $P($. $)$ is the conditional probability that $s_{t}$ will take the value $j$.

For the two-state case the density distribution of $r_{f, t}$ is, following Hamilton (1994, Chapter 22)

$g\left(r_{f, t} \mid Y_{t-1}, \psi\right)=\frac{1}{\sqrt{2 \pi \sigma_{1}^{2}}} \exp \left\{\frac{-u_{r_{f}, 1 t}^{2}}{2 \sigma_{1}^{2}}\right\}+\frac{1}{\sqrt{2 \pi \sigma_{2}^{2}}} \exp \left\{\frac{-u_{r_{f}, 2 t}^{2}}{2 \sigma_{2}^{2}}\right\}$

where $u_{r_{f}, s_{t} t}$ is the residual of equation (10).

If the unobserved state variable $s_{t}$ is i.i.d. maximum likelihood estimates of the parameters in $\psi$ are obtained maximizing the following log likelihood function with respect to the unknown parameters

$\mathrm{L}(\psi)=\sum_{t=1}^{T} \log g\left(r_{f, t} \mid Y_{t-1}, \psi\right)$

where $\mathrm{T}$ is the total number of sample observations.

In this paper we base the identification process of the nature of the regimes, essential for the interpretation of a Markov switching model, on 
the estimates of equation (10) and on the analysis of the behavior over time of the state probabilities.

\section{< INSERT TABLE 9 ABOUT HERE >}

In Table 9 are set out the estimates of equation (10) for the five commodity markets. The quality of fit is highly satisfactory since, with the exception of cotton, the relevant coefficients change across regimes and are significantly different from zero. The restriction of equal residual variances is strongly rejected by LR tests performed for each model. The regime (state) 2 variances are from two to three time larger than those of regime (state) 1 . The probability of switching from a low variance to a high variance state $p_{12}$ is lower than the probability of switching from a high variance to a low variance state $p_{21}$. For instance, in the case of oil, the transition probabilities are $p_{12}=0.9 \%$ and $p_{21}=6.5 \%$; these findings indicate that the average expected duration of being in state 1 is close to 111 working days (about 5 months) and the average expected duration of being in state 2 is of 15 working days. ${ }^{11}$ The number of days of high volatility is, on the whole, rather small.

A relevant difference across regimes in hedging and speculative behavior can be easily detected. The reaction of hedgers is not homogeneous in the various markets. In the case of copper and soybeans hedgers seem to be more sensitive to portfolio risk in state 2 while in the remaining markets the opposite reaction can be detected. The behavior of speculators too changes with the market. In the case of copper and soybeans a risk averse behavior in state 1 is reversed with the change of regime; speculators increase their demand for futures contracts whenever the volatility rises. In the remaining markets speculators behave in the opposite way. Their reaction to (a high) futures return volatility decreases in the case of oil and becomes nil in the case cotton and silver. This finding is of interest for the interpretation of the main drivers of the volatility movements for these commodities. It suggests that volatility changes, in regime 2, may be due more to spillovers from monetary,

\footnotetext{
${ }^{11}$ The average expected duration of being in state 1 is computed according to Hamilton (1989) as $\sum_{i=1}^{\infty} i p_{11}^{i-1}\left(1-p_{11}\right)=\left(1-p_{11}\right)^{-1}=\left(p_{12}\right)^{-1}$
} 
financial, and exchange rate markets than to endogenous market speculation.

The estimates of the weighted coefficient ratio (SPEC) set forth in Table 9 strongly suggest that in state 2 the impact of speculation on futures price dynamics is much stronger than in state 1 of the market. Finally, the optimal hedge ratio $\beta$ tends to increase during the high volatility period in the case of oil, silver, and copper (a result due to the significant increase in correlation between spot and futures returns), while for cotton and soybeans the reverse holds true. ${ }^{12}$

$$
\begin{aligned}
& <\text { INSERT FIGURE } 1 \text { ABOUT HERE > } \\
& <\text { INSERT FIGURE } 2 \text { ABOUT HERE > } \\
& <\text { INSERT FIGURE } 3 \text { ABOUT HERE > }
\end{aligned}
$$

Figures 1 to 3 provide useful insights on the dating of the regime shifts. In the upper graph of each figure is set forth the behavior over the sample of the time t probability that the market is in regime 1 . In the lower graph is set out the rate of return of the corresponding futures contract. Visual inspection suggests that regime 1 may be associated with periods in which return variability is low (and thus regime 2 with periods in which it is high). ${ }^{13}$

\section{< INSERT TABLE 10 ABOUT HERE >}

In table 10 are finally reported the correlation coefficients between the probability 1 regime and the daily rate of return and standard deviation of the corresponding futures contract. As expected, we find a large negative and significant correlation coefficient between the regime 1 probabilities and the daily standard deviations. We detect, however, also a significant positive correlation of these regime probabilities with futures returns. This result indicates, especially for silver, a more complex identification of the nature of the state variable $s_{t}$. Regime 1 is to be associated with both low futures return variability and, to a lesser extent, with positive futures price

\footnotetext{
12 The correlation between the spot and futures returns is generally stronger in the high volatility regime. In the case of cotton and soybeans, however, the increase is small (3.75 and 1.16 percent, respectively). This lack of reaction to volatility shifts may explain the portfolio risk minimization results of Table 8 , where, for these commodities, the timevarying conditional hedge ratios are outperformed by the constant OLS optimal hedges.

${ }^{13}$ For each market, bouts of high variability are clearly identified. They do not coincide in the first half of the sample and tend to be more synchronized in the second half, a symptom of the growing financial integration of the commodity markets.
} 
rates of change (i.e. possibly with a bullish market), and regime 2 with high return variability and negative futures price rates of change (i.e. with a bearish market). ${ }^{14}$

\section{Conclusions}

This paper examines the dynamic behavior of futures returns on five commodity markets. The interaction between hedgers and speculators is modelled using a highly non linear parameterization where hedgers react to deviations from the minimum variance of the hedged portfolio and speculators respond to standard expected risk returns considerations. The relationship between expected spot and futures returns and time varying volatilities is estimated using a non linear in mean CCC-GARCH approach. The results point to the suitability of this choice because of the quality of fit and of the sensible meaning of the model's parameter estimates.

In spite of the growing role of speculation, over the 1990-2010 sample period, hedgers do play a relevant role since futures returns dynamics is mostly associated with the variability of the hedged portfolio, especially in the low volatility regime.

We account for the impact of financial integration of the commodity markets by allowing the demand of futures to be dependent upon the "state of the market" via a Markov regime switching approach. Both visual inspection and correlation analysis suggest that regime 1 be associated with periods in which return variability is low and regime 2 with periods in which it is high. Optimal hedging ratios computed in each state are larger in high volatility regimes for oil, copper and silver, while the reverse holds true for cotton and soybeans. The differences across regimes in hedging and speculative behavior are distinctive and not homogeneous across commodities. The role of speculators appears to be very strong, and significant, when market volatility is high in the case of copper, soybeans, and oil. However, the positive correlation of the regime probabilities with the futures daily rates of returns suggests, especially for silver, a more complex identification of the nature of the state variable. Thus further

\footnotetext{
${ }^{14}$ According to the standard ADF unit root tests, the time $t$ regime 1 probability time series are always $\mathrm{I}(0)$.
} 
investigation, e.g. introducing a four regime framework, could provide additional insights about the nature of the volatility of the futures returns for some of the commodities of our study.

TABLE 1 Descriptive statistics

Daily sample from 3 January 1990 to 26 January 2010 (5325 observations)

\begin{tabular}{|l|c|c|c|r|r|r|r|}
\hline Return & Mean & St.dev. & \multicolumn{1}{c|}{ Sk. } & \multicolumn{1}{|c|}{ Kurt. } & \multicolumn{1}{c|}{ JB } & \multicolumn{1}{c|}{ ARCH(1)[pr.] } & \multicolumn{1}{|c|}{ ARCH(5)[pr.] } \\
\hline Copper futures & 0.000229 & 0.0169 & -0.22 & 4.53 & 4520.46 & $181.57[0.00]$ & $570.36[0.00]$ \\
\hline Copper cash & 0.000210 & 0.0169 & -0.21 & 4.51 & 4483.09 & $346.76[0.00]$ & $876.66[0.00]$ \\
\hline Cotton futures & 0.000112 & 0.0175 & -0.79 & 22.07 & 106878.63 & $14.45[0.00]$ & $91.93[0.00]$ \\
\hline Cotton cash & 0.000122 & 0.0174 & 0.02 & 2.43 & 1290.37 & $177.66[0.00]$ & $843.85[0.00]$ \\
\hline Oil futures & 0.000270 & 0.0250 & -0.95 & 17.52 & 67710.6 & $73.16[0.00]$ & $365.74[0.00]$ \\
\hline Oil cash & 0.000240 & 0.0240 & -1.23 & 24.63 & 1333762.2 & $20.55[0.00]$ & $94.68[0.00]$ \\
\hline Silver futures & 0.000220 & 0.0165 & -0.39 & 6.89 & 10498.5 & $120.53[0.00]$ & $401.85[0.00]$ \\
\hline Silver cash & 0.000220 & 0.0177 & -0.23 & 4.40 & 3521.0 & $121.88[0.00]$ & $334.44[0.00]$ \\
\hline Soybeans futures & 0.000095 & 0.0148 & -0.59 & 5.94 & 8020.7 & $29.21[0.00]$ & $206.73[0.00]$ \\
\hline Soybeans cash & 0.000097 & 0.0152 & -0.75 & 7.24 & 11964.7 & $60.45[0.00]$ & $360.72[0.00]$ \\
\hline
\end{tabular}

Notes: Sk.: skewness; Kurt.: kurtosis; JB: Jarque Bera test statistic; ARCH(.): Lagrange Multiplier test foth the kth order Arch, probability levels are in square brackets. These notes also apply to the following tables. 
TABLE 2 Copper

$a_{2} r_{c, t-2} ; a_{3} r_{f, t-1} ; a_{4} r_{f, t-2}$

\begin{tabular}{|c|c|c|c|c|c|}
\hline \multicolumn{3}{|c|}{ Conditional Mean Equation } & \multicolumn{3}{|c|}{ Conditional Variance Equation } \\
\hline & $r_{c, t}$ & $r_{f, t}$ & & $h_{c, t}^{2}$ & $h_{f, t}^{2}$ \\
\hline$a_{0}$ & $\begin{array}{c}0.010 \\
(21.45)\end{array}$ & & $\varpi$ & $\begin{array}{l}8.9 \mathrm{E}-06 \\
(37.18)\end{array}$ & $\begin{array}{l}1.0 \mathrm{e}-05 \\
(13.43)\end{array}$ \\
\hline$a_{1}$ & $\begin{array}{c}-0.303 \\
(-27.26)\end{array}$ & & $\alpha$ & $\begin{array}{c}0.907 \\
(314.72)\end{array}$ & $\begin{array}{c}0.904 \\
(448.05)\end{array}$ \\
\hline$a_{2}$ & $\begin{array}{c}0.247 \\
(28.50)\end{array}$ & & $\beta$ & $\begin{array}{c}0.058 \\
(21.59)\end{array}$ & $\begin{array}{c}0.054 \\
(54.59)\end{array}$ \\
\hline$a_{3}$ & $\begin{array}{c}-0.172 \\
(-17.07)\end{array}$ & & $\rho_{12}$ & \multicolumn{2}{|c|}{$\begin{array}{c}0.878 \\
(696.38)\end{array}$} \\
\hline$a_{4}$ & $\begin{array}{c}0.161 \\
(16.94)\end{array}$ & & $\begin{array}{l}\text { Funct } \\
\text { Value }\end{array}$ & \multicolumn{2}{|c|}{32667.4212} \\
\hline$\varepsilon_{1}$ & $\begin{array}{c}0.036 \\
(151.44)\end{array}$ & & & & \\
\hline$d_{0}$ & $\begin{array}{c}0.249 \\
(27.93\end{array}$ & & & & \\
\hline$d_{1}$ & $\begin{array}{c}1.005 \\
(203.40)\end{array}$ & & & & \\
\hline$e_{0}$ & & $\begin{array}{l}-1.0 \mathrm{E}-04 \\
(-194.48)\end{array}$ & & & \\
\hline$b^{H}$ & & $\begin{array}{c}-9.526 \\
(-19.76)\end{array}$ & & & \\
\hline$e^{S}$ & & $\begin{array}{c}-2.165 \\
(-19.40)\end{array}$ & & & \\
\hline$d^{S}$ & & $\begin{array}{l}0.370 \\
(1516)\end{array}$ & & & \\
\hline$E\left[v_{t}\right]$ & $\begin{array}{c}0.02 \\
(1.67)\end{array}$ & $\begin{array}{c}0.02 \\
(1.58)\end{array}$ & & & \\
\hline$E\left[v_{t}^{2}\right]$ & 0.99 & 0.99 & & & \\
\hline Sk. & -0.34 & -0.19 & & & \\
\hline Kurt. & 3.77 & 2.88 & & & \\
\hline $\mathrm{ARCH}(1)$ & $\begin{array}{c}0.24 \\
{[0.63]}\end{array}$ & $\begin{array}{c}2.74 \\
{[0.10]}\end{array}$ & & & \\
\hline $\operatorname{ARCH}(6)$ & $\begin{array}{c}3.00 \\
{[0.81]}\end{array}$ & $\begin{array}{c}5.12 \\
{[0.53]}\end{array}$ & & & \\
\hline$J B$ & 3214.64 & 1840.19 & & & \\
\hline
\end{tabular}

Note: An AR(1) filter pre-whitens the futures returns time series;

$v_{\mathrm{t}}$ : standardized conditional mean residual. 
TABLE 3 Cotton

$a_{2} r_{f, t-1} ; a_{3} r_{f, t-2} ; a_{4} r_{s, t-2}$ in the cash return eq.; $k:$ dummy in the futures return eq.

\begin{tabular}{|c|c|c|c|c|c|}
\hline \multicolumn{3}{|c|}{ Conditional Mean Equation } & \multicolumn{3}{|c|}{ Conditional Variance Equation } \\
\hline & $r_{c, t}$ & $r_{f, t}$ & & $h_{c, t}^{2}$ & $h_{f, t}^{2}$ \\
\hline$a_{0}$ & $\begin{array}{c}-0.0179 \\
(-248.61)\end{array}$ & & $\varpi$ & $\begin{array}{l}9.0 \mathrm{e}-06 \\
(113.66)\end{array}$ & $\begin{array}{l}1.2 \mathrm{e}-05 \\
(91.29)\end{array}$ \\
\hline$a_{1}$ & $\begin{array}{l}-0.081 \\
(-8.94)\end{array}$ & & $\alpha$ & $\begin{array}{c}0.913 \\
(996.6)\end{array}$ & $\begin{array}{c}0.885 \\
(1485.67)\end{array}$ \\
\hline$a_{2}$ & $\begin{array}{c}0.084 \\
(13.62)\end{array}$ & & $\beta$ & $\begin{array}{c}0.053 \\
(59.05)\end{array}$ & $\begin{array}{c}0.074 \\
(105.90)\end{array}$ \\
\hline$a_{3}$ & $\begin{array}{l}-0.026 \\
(-3.42)\end{array}$ & & $\rho_{12}$ & & \\
\hline$\varepsilon_{1}$ & $\begin{array}{c}0.030 \\
(115.93)\end{array}$ & & Funct. value & & \\
\hline$d_{0}$ & $\begin{array}{c}-0.291 \\
(-136.79)\end{array}$ & & & & \\
\hline$d_{1}$ & $\begin{array}{c}0.939 \\
(1030.11)\end{array}$ & & & & \\
\hline$e_{0}$ & & $\begin{array}{l}-5.6 e-04 \\
(-8.08)\end{array}$ & & & \\
\hline$b^{H}$ & & $\begin{array}{c}-0.365 \\
(-14.09)\end{array}$ & & & \\
\hline$e^{S}$ & & $\begin{array}{r}-0.067 \\
(-7.98)\end{array}$ & & & \\
\hline$d^{S}$ & & $\begin{array}{l}0.039 \\
(6.72)\end{array}$ & & & \\
\hline$k$ & & $\begin{array}{c}-0.280 \\
(-44.68)\end{array}$ & & & \\
\hline$E\left[v_{t}\right]$ & $\begin{array}{l}0.007 \\
(0.50)\end{array}$ & $\begin{array}{l}0.005 \\
(0.36)\end{array}$ & & & \\
\hline$E\left[v_{t}^{2}\right]$ & 1.000 & 1.000 & & & \\
\hline Sk. & -0.008 & 0.03 & & & \\
\hline Kurt. & 1.66 & 4.09 & & & \\
\hline $\mathrm{ARCH}(1)$ & $\begin{array}{c}0.77 \\
{[0.38]}\end{array}$ & $\begin{array}{l}0.003 \\
{[0.95]}\end{array}$ & & & \\
\hline $\mathrm{ARCH}(6)$ & $\begin{array}{c}0.28 \\
{[0.21]}\end{array}$ & $\begin{array}{c}5.51 \\
{[0.47]}\end{array}$ & & & \\
\hline$J B$ & 602.16 & 3648.43 & & & \\
\hline
\end{tabular}


TABLE 4 Oil

$\gamma$ : the asymmetry coefficient ; $a_{1} r_{c, t-1} ; a_{2} r_{f, t-1} ; a_{3} r_{c, t-2} ; a_{4} r_{f, t-2} ; a_{5} r_{c, t-3} ; a_{6} r_{f, t-3}$

\begin{tabular}{|c|c|c|c|c|c|}
\hline \multicolumn{3}{|c|}{ Conditional Mean Equation } & \multicolumn{3}{|c|}{ Conditional Variance Equation } \\
\hline & $r_{c, t}$ & $r_{f, t}$ & & $h_{c, t}^{2}$ & $h_{f, t}^{2}$ \\
\hline$a_{0}$ & $\begin{array}{c}-0.012 \\
(-86.90)\end{array}$ & & $\varpi$ & $\begin{array}{l}1.9 e-05 \\
(65.65)\end{array}$ & $\begin{array}{l}2.2 \mathrm{e}-05 \\
(39.09)\end{array}$ \\
\hline$a_{1}$ & $\begin{array}{c}-0.219 \\
(-25.74)\end{array}$ & & $\alpha$ & $\begin{array}{c}0.866 \\
(691.56)\end{array}$ & $\begin{array}{c}0.850 \\
(577.38)\end{array}$ \\
\hline$a_{2}$ & $\begin{array}{c}0.235 \\
(32.58)\end{array}$ & & $\beta$ & $\begin{array}{c}0.097 \\
(82.38)\end{array}$ & $\begin{array}{c}0.099 \\
(55.07)\end{array}$ \\
\hline$\varepsilon_{1}$ & $\begin{array}{c}0.065 \\
(89.90)\end{array}$ & & $\gamma$ & & $\begin{array}{l}0.029 \\
(9.30)\end{array}$ \\
\hline$d_{0}$ & -- & & $\rho_{12}$ & & \\
\hline$d_{1}$ & $\begin{array}{c}0.957 \\
(1547.6)\end{array}$ & & Funct. value & 27 & 94 \\
\hline$e_{0}$ & & $\begin{array}{l}2.06 e-04 \\
(1.51)\end{array}$ & & & \\
\hline$b^{H}$ & & $\begin{array}{r}0.787 \\
(5.51)\end{array}$ & & & \\
\hline$e^{S}$ & & $\begin{array}{l}0.448 \\
(7.62)\end{array}$ & & & \\
\hline$d^{S}$ & & $\begin{array}{r}0.186 \\
(3.45)\end{array}$ & & & \\
\hline$E\left[v_{t}\right]$ & $\begin{array}{l}-0.016 \\
(-1.16)\end{array}$ & $\begin{array}{l}-0.012 \\
(-0.89)\end{array}$ & & & \\
\hline$E\left[v_{t}^{2}\right]$ & 0.999 & 1.000 & & & \\
\hline Sk. & -0.29 & -0.33 & & & \\
\hline Kurt. & 4.55 & 3.08 & & & \\
\hline $\mathrm{ARCH}(1)$ & $\begin{array}{c}0.59 \\
{[0.44]}\end{array}$ & $\begin{array}{c}4.76 \\
{[0.03]}\end{array}$ & & & \\
\hline $\mathrm{ARCH}(6)$ & $\begin{array}{l}12.07 \\
{[0.06]}\end{array}$ & $\begin{array}{c}1.63 \\
{[0.95]}\end{array}$ & & & \\
\hline$J B$ & 4591.16 & 2167.16 & & & \\
\hline
\end{tabular}


TABLE 5 Silver

\begin{tabular}{|c|c|c|c|c|c|}
\hline \multicolumn{3}{|c|}{ Conditional Mean Equation } & \multicolumn{3}{|c|}{ Conditional Variance Equation } \\
\hline & $r_{c, t}$ & $r_{f, t}$ & & $h_{c, t}^{2}$ & $h_{f, t}^{2}$ \\
\hline$a_{0}$ & $\begin{array}{c}0.002 \\
(26.22)\end{array}$ & & $\varpi$ & $\begin{array}{c}7.0 \mathrm{e}-06 \\
(88.20)\end{array}$ & $\begin{array}{l}9.0 \mathrm{e}-06 \\
(74.88)\end{array}$ \\
\hline$a_{1}$ & $\begin{array}{c}-0.143 \\
(-22.75)\end{array}$ & & $\alpha$ & $\begin{array}{c}0.896 \\
(1071.1)\end{array}$ & $\begin{array}{c}0.905 \\
(1238.1)\end{array}$ \\
\hline$a_{2}$ & $\begin{array}{c}0.164 \\
(43.36)\end{array}$ & & $\beta$ & $\begin{array}{c}0.069 \\
(76.05)\end{array}$ & $\begin{array}{c}0.059 \\
(71.29)\end{array}$ \\
\hline$\varepsilon_{1}$ & $\begin{array}{c}0.592 \\
(142.88)\end{array}$ & & $\gamma$ & & \\
\hline$d_{0}$ & $\begin{array}{l}-0.0038 \\
(29.75)\end{array}$ & & $\rho_{12}$ & & \\
\hline$d_{1}$ & $\begin{array}{c}1.000 \\
(49342.6)\end{array}$ & & Funct. value & 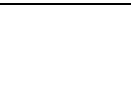 & \\
\hline$e_{0}$ & & $\begin{array}{l}0.0002 \\
(2.65)\end{array}$ & & & \\
\hline$b^{H}$ & & $\begin{array}{l}0.202 \\
(9.32)\end{array}$ & & & \\
\hline$e_{2}$ & & $\begin{array}{l}0.032 \\
(6.07)\end{array}$ & & & \\
\hline$e_{3}$ & & $\begin{array}{l}0.013 \\
(3.88)\end{array}$ & & & \\
\hline$E\left[v_{t}\right]$ & $\begin{array}{c}0.03 \\
(1.94)\end{array}$ & $\begin{array}{c}0.02 \\
(1.61)\end{array}$ & & & \\
\hline$E\left[v_{t}^{2}\right]$ & 0.999 & 0.999 & & & \\
\hline Sk. & -0.38 & -0.31 & & & \\
\hline Kurt. & 4.62 & 3.83 & & & \\
\hline $\mathrm{ARCH}(1)$ & $\begin{array}{c}4.22 \\
{[0.04]}\end{array}$ & $\begin{array}{c}1.49 \\
{[0.22]}\end{array}$ & & & \\
\hline $\mathrm{ARCH}(6)$ & $\begin{array}{c}13.07 \\
{[0.04]}\end{array}$ & $\begin{array}{c}9.76 \\
{[0.13]}\end{array}$ & & & \\
\hline$J B$ & 4793.24 & 3284.07 & & & \\
\hline
\end{tabular}


TABLE 6 Soybeans

\begin{tabular}{|c|c|c|c|c|c|}
\hline \multicolumn{3}{|c|}{ Conditional Mean Equation } & \multicolumn{3}{|c|}{ Conditional Variance Equation } \\
\hline & $r_{c, t}$ & $r_{f, t}$ & & $h_{c, t}^{2}$ & $h_{f, t}^{2}$ \\
\hline$a_{0}$ & $\begin{array}{c}0.003 \\
(41.43)\end{array}$ & & $\varpi$ & $\begin{array}{c}2.0 \mathrm{e}-06 \\
(26.77)\end{array}$ & $\begin{array}{r}2.0 \mathrm{e}-06 \\
(32.0)\end{array}$ \\
\hline$a_{1}$ & $\begin{array}{c}-0.231 \\
(-39.22)\end{array}$ & & $\alpha$ & $\begin{array}{c}0.920 \\
(1861.1)\end{array}$ & $\begin{array}{c}0.934 \\
(3072.8)\end{array}$ \\
\hline$a_{2}$ & $\begin{array}{c}0.215 \\
(41.30)\end{array}$ & & $\beta$ & $\begin{array}{c}0.072 \\
(160.59)\end{array}$ & $\begin{array}{c}0.058 \\
(178.19)\end{array}$ \\
\hline$\varepsilon_{1}$ & $\begin{array}{c}0.047 \\
(59.49)\end{array}$ & & $\rho_{12}$ & \multicolumn{2}{|c|}{$\begin{array}{c}0.884 \\
(1657.4)\end{array}$} \\
\hline$d_{0}$ & $\begin{array}{c}0.09 \\
(65.68)\end{array}$ & & Funct. Value & \multicolumn{2}{|c|}{34179.3979} \\
\hline$d_{1}$ & $\begin{array}{c}0.997 \\
(4670.9)\end{array}$ & & & & \\
\hline$e_{0}$ & & $\begin{array}{l}0.0003 \\
(4.90)\end{array}$ & & & \\
\hline$b^{H}$ & & $\begin{array}{c}-48.24 \\
(-12.62)\end{array}$ & & & \\
\hline$e^{S}$ & & $\begin{array}{c}-14.48 \\
(-17.67)\end{array}$ & & & \\
\hline$d^{S}$ & & $\begin{array}{c}2.45 \\
(7.38)\end{array}$ & & & \\
\hline$E\left[v_{t}\right]$ & $\begin{array}{l}0.010 \\
(0.74)\end{array}$ & $\begin{array}{l}0.012 \\
(0.88)\end{array}$ & & & \\
\hline$E\left[v_{t}^{2}\right]$ & 1.00 & 1.00 & & & \\
\hline Sk. & -0.21 & -0.02 & & & \\
\hline Kurt. & 2.71 & 2.88 & & & \\
\hline $\mathrm{ARCH}(1)$ & $\begin{array}{c}1.95 \\
{[0.16]}\end{array}$ & $\begin{array}{c}0.58 \\
{[0.45]}\end{array}$ & & & \\
\hline $\operatorname{ARCH}(6)$ & $\begin{array}{c}5.11 \\
{[0.53]}\end{array}$ & $\begin{array}{c}3.74 \\
{[0.71]}\end{array}$ & & & \\
\hline$J B$ & 1646.9 & 1814.2 & & & \\
\hline
\end{tabular}


TABLE 7 Relative importance of speculative drivers on futures pricing (absolute value of $e^{S} \sigma_{r_{f}, t}^{2} / b^{H} \sigma_{r_{c}, t}^{2}\left(1-\rho_{r_{c} r_{f}, t}^{2}\right)$ )

\begin{tabular}{|l|l|}
\hline Copper & 1.03 \\
\hline Cotton & 0.44 \\
\hline Oil & 1.34 \\
\hline Silver & 0.37 \\
\hline Soybeans & 1.13 \\
\hline
\end{tabular}

TABLE 8 Optimal hedge ratios and portfolio second moments

\begin{tabular}{|l|c|c||c|c||c|}
\hline & \multicolumn{2}{|c|}{ CCC-GARCH Estimates } & \multicolumn{2}{c|}{ OLS Estimates } & Naïve \\
\hline & $\begin{array}{c}\text { Optimal } \\
\text { hedge } \\
\text { ratio } \beta\end{array}$ & $\begin{array}{c}\text { St. Dev. of the } \\
\text { optimal hedge } \\
\text { portfolio }\end{array}$ & $\begin{array}{c}\text { Optimal } \\
\text { hedge } \\
\text { ratio } \beta\end{array}$ & $\begin{array}{c}\text { St. Dev. of the } \\
\text { optimal hedge } \\
\text { portfolio }\end{array}$ & $\begin{array}{c}\text { St. Dev. of the } \\
\text { naive portfolio }\end{array}$ \\
\hline Copper & 0.87 & 0.008240 & 0.91 & 0.008374 & 0.008518 \\
\hline Cotton & 0.81 & 0.011268 & 0.76 & 0.011179 & 0.011894 \\
\hline Oil & 0.74 & 0.016322 & 0.70 & 0.016416 & 0.018017 \\
\hline Silver & 0.71 & 0.010867 & 0.72 & 0.010868 & 0.011857 \\
\hline Soybeans & 0.90 & 0.007627 & 0.89 & 0.007605 & 0.007770 \\
\hline
\end{tabular}


TABLE 9 Markov switching regime estimates of equation (10)

\begin{tabular}{|c|c|c|c|c|c|c|c|c|c|c|}
\hline & \multicolumn{2}{|c|}{ Copper } & \multicolumn{2}{|c|}{ Cotton } & \multicolumn{2}{|c|}{ Oil } & \multicolumn{2}{|c|}{ Silver } & \multicolumn{2}{|c|}{ Soybeans } \\
\hline & $s t=1$ & $s t=2$ & $s t=1$ & $s t=2$ & $\mathrm{St}=1$ & $s t=2$ & $s t=1$ & $s t=2$ & $s t=1$ & $\mathrm{st}=2$ \\
\hline$p_{s t, n o t s t}$ & $\begin{array}{l}0.023 \\
(9.10)\end{array}$ & $\begin{array}{l}0.066 \\
(9.73)\end{array}$ & $\begin{array}{c}0.054 \\
(11.50)\end{array}$ & $\begin{array}{c}0.216 \\
(13.26)\end{array}$ & $\begin{array}{l}0.009 \\
(6.00)\end{array}$ & $\begin{array}{l}0.065 \\
(7.21)\end{array}$ & $\begin{array}{c}0.070 \\
(11.77)\end{array}$ & $\begin{array}{c}0.173 \\
(14.55)\end{array}$ & $\begin{array}{c}0.034 \\
(10.26)\end{array}$ & $\begin{array}{c}0.084 \\
(10.59)\end{array}$ \\
\hline$e_{0 s t}$ & $\begin{array}{l}-0.001 \\
(-4.76)\end{array}$ & $\begin{array}{l}0.002 \\
(3.16)\end{array}$ & $\begin{array}{l}-0.000 \\
(-2.14)\end{array}$ & $\begin{array}{l}-0.002 \\
(-1.65)\end{array}$ & $\begin{array}{l}-0.000 \\
(0.68)\end{array}$ & $\begin{array}{l}-0.002 \\
(-1.26)\end{array}$ & $\begin{array}{c}-0.001 \\
(-12.18)\end{array}$ & $\begin{array}{l}-0.001 \\
(-1.04)\end{array}$ & $\begin{array}{l}-0.000 \\
(-0.69)\end{array}$ & $\begin{array}{l}0.002 \\
(4.25)\end{array}$ \\
\hline$b_{s t}^{H}$ & $\begin{array}{l}-0.479 \\
(-4.11)\end{array}$ & $\begin{array}{l}-3.756 \\
(-5.98)\end{array}$ & $\begin{array}{l}-0.164 \\
(-3.55)\end{array}$ & $\begin{array}{l}-0.067 \\
(-0.67)\end{array}$ & $\begin{array}{l}1.884 \\
(5.96)\end{array}$ & $\begin{array}{l}0.742 \\
(4.04)\end{array}$ & $\begin{array}{c}-0.337 \\
(-19.57)\end{array}$ & $\begin{array}{l}0.164 \\
(2.68)\end{array}$ & $\begin{array}{l}4.237 \\
(3.24)\end{array}$ & $\begin{array}{l}-5.641 \\
(-2.04)\end{array}$ \\
\hline$e_{s t}^{s}$ & $\begin{array}{l}0.108 \\
(3.62)\end{array}$ & $\begin{array}{l}-1.915 \\
(-12.2)\end{array}$ & $\begin{array}{l}0.014 \\
(0.77)\end{array}$ & $\begin{array}{l}-0.010 \\
(-0.25)\end{array}$ & $\begin{array}{l}1.335 \\
(9.54)\end{array}$ & $\begin{array}{l}0.235 \\
(4.28)\end{array}$ & $\begin{array}{l}-0.008 \\
(-1.91)\end{array}$ & $\begin{array}{l}0.021 \\
(1.31)\end{array}$ & $\begin{array}{l}1.628 \\
(5.45)\end{array}$ & $\begin{array}{l}-5.767 \\
(-7.68)\end{array}$ \\
\hline$d_{s t}^{S}$ & $\begin{array}{l}0.034 \\
(7.63)\end{array}$ & $\begin{array}{l}0.178 \\
(6.23)\end{array}$ & $\begin{array}{l}0.026 \\
(4.30)\end{array}$ & $\begin{array}{l}0.019 \\
(0.43)\end{array}$ & $\begin{array}{l}0.265 \\
(4.43)\end{array}$ & $\begin{array}{l}0.066 \\
(1,81)\end{array}$ & $\begin{array}{c}0.007 \\
(15.94)\end{array}$ & $\begin{array}{l}0.015 \\
(1.44)\end{array}$ & $\begin{array}{l}0.373 \\
(2.46)\end{array}$ & $\begin{array}{l}0.648 \\
(5.79)\end{array}$ \\
\hline$\sigma_{s t}^{2}$ & $\begin{array}{c}0.012 \\
(75.94)\end{array}$ & $\begin{array}{c}0.027 \\
(54.68)\end{array}$ & $\begin{array}{c}0.012 \\
(72.00)\end{array}$ & $\begin{array}{c}0.030 \\
(109.3)\end{array}$ & $\begin{array}{c}0.018 \\
(94.79)\end{array}$ & $\begin{array}{c}0.048 \\
(37.31)\end{array}$ & $\begin{array}{c}0.010 \\
(79.15)\end{array}$ & $\begin{array}{c}0.028 \\
(67.26)\end{array}$ & $\begin{array}{c}0.010 \\
(69.30)\end{array}$ & $\begin{array}{c}0.023 \\
(71.17)\end{array}$ \\
\hline $\begin{array}{l}\text { n. of days } \\
\text { in } \mathrm{s}_{\mathrm{t}}{ }^{*}\end{array}$ & 43 & 15 & 19 & 7 & 111 & 15 & 14 & 8 & 29 & 12 \\
\hline SPEC & 0.60 & 2.96 & 0.26 & 0.34 & 1.16 & 3.76 & 0.05 & 0.40 & 1.25 & 4.23 \\
\hline $\begin{array}{c}\text { Optimal h. } \\
\text { ratio } \beta\end{array}$ & 0.86 & 0.93 & 0.92 & 0.68 & 0.88 & 0.96 & 0.73 & 0.87 & 0.94 & 0.87 \\
\hline $\begin{array}{l}\text { Function } \\
\text { value }\end{array}$ & \multicolumn{2}{|c|}{14444.017} & \multicolumn{2}{|c|}{14250.008} & \multicolumn{2}{|c|}{12672.172} & \multicolumn{2}{|c|}{14568.325} & \multicolumn{2}{|c|}{15168.223} \\
\hline LR & \multicolumn{2}{|c|}{$\begin{array}{c}538 \\
{[0.00]}\end{array}$} & \multicolumn{2}{|c|}{$\begin{array}{c}684 \\
{[0.00]}\end{array}$} & \multicolumn{2}{|c|}{$\begin{array}{c}692 \\
{[0.00]}\end{array}$} & \multicolumn{2}{|c|}{$\begin{array}{c}852 \\
{[0.00]}\end{array}$} & \multicolumn{2}{|c|}{$\begin{array}{c}60 \\
{[0.00]}\end{array}$} \\
\hline
\end{tabular}

Notes: *: Average expected duration of being in state $s_{t} ;$ SPEC: speculative to hedging factors ratio defined as $e^{S} \sigma_{r_{f}, t}^{2} / b^{H} \sigma_{r_{c}, t}^{2}\left(1-\rho_{r_{c} r_{f}, t}^{2}\right)$; LR: Likelihod Ratio test of the null hypothesis $H_{0}$ : $\sigma_{1}^{2}=\sigma_{2}^{2}$, distributed $\chi^{2}$ with 1 degree of freedom.

TABLE 10 Correlation between regime 1 probability and daily futures returns and standard deviations

\begin{tabular}{|l|c|c|c|c|c|}
\hline & Copper & Cotton & Oil & Silver & Soybeans \\
\hline$r_{f, t}$ & 0.032 & 0.051 & 0.077 & 0.113 & 0.029 \\
& $(2.54)$ & $(3.62)$ & $(5.42)$ & $(8.02)$ & $(2.08)$ \\
\hline$\sigma_{r_{f, t}}$ & -0.601 & -0.715 & -0.554 & -0.716 & -0.627 \\
& $(-52.98)$ & $(-72.02)$ & $(-4.96)$ & $(-72.21)$ & $(-56.77)$ \\
\hline
\end{tabular}


FIGURE 1
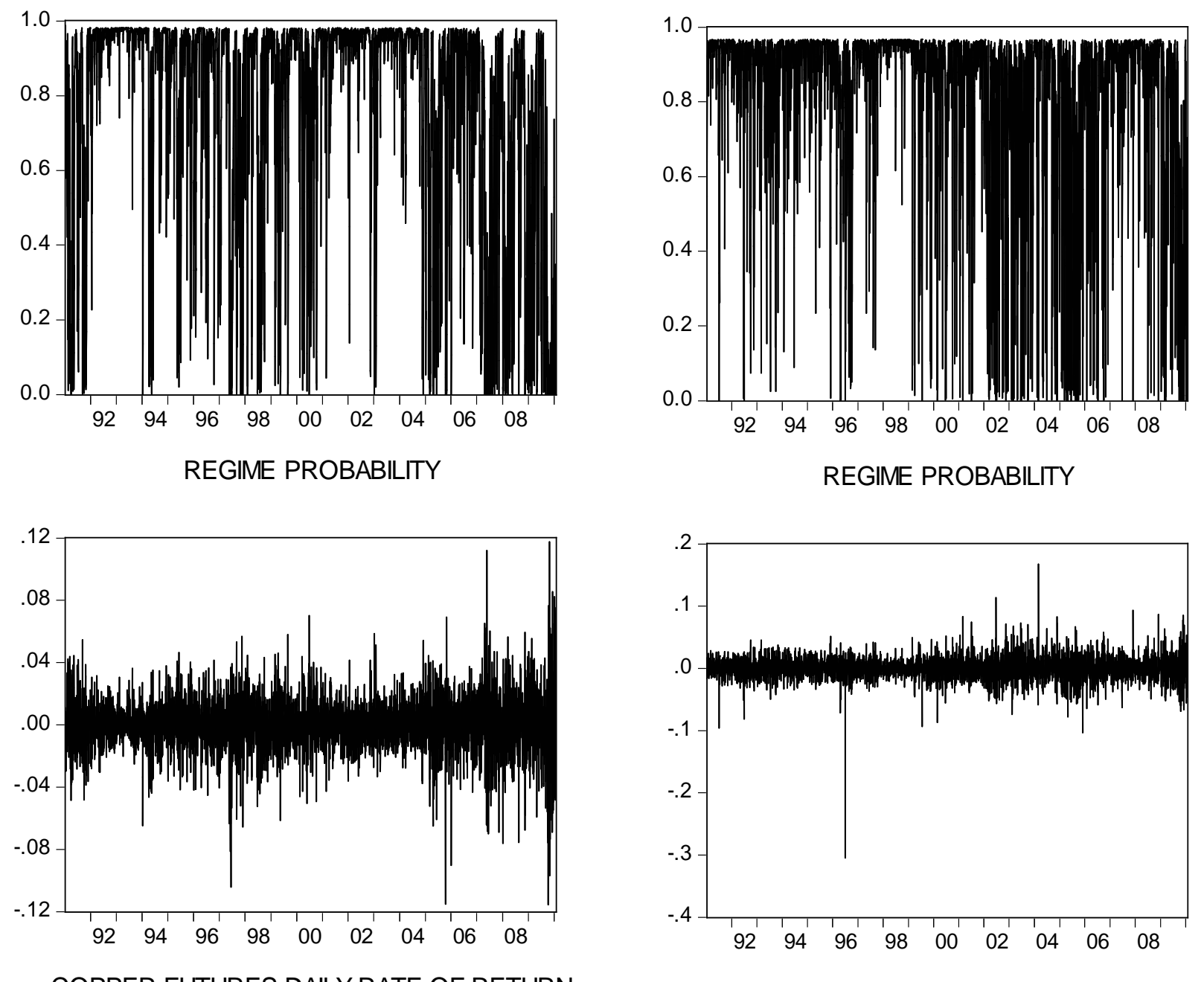
COPPER FUTURES DAILY RATE OF RETURN COTTON FUTURES DAILY RATE OF RETURN 
FIGURE 2

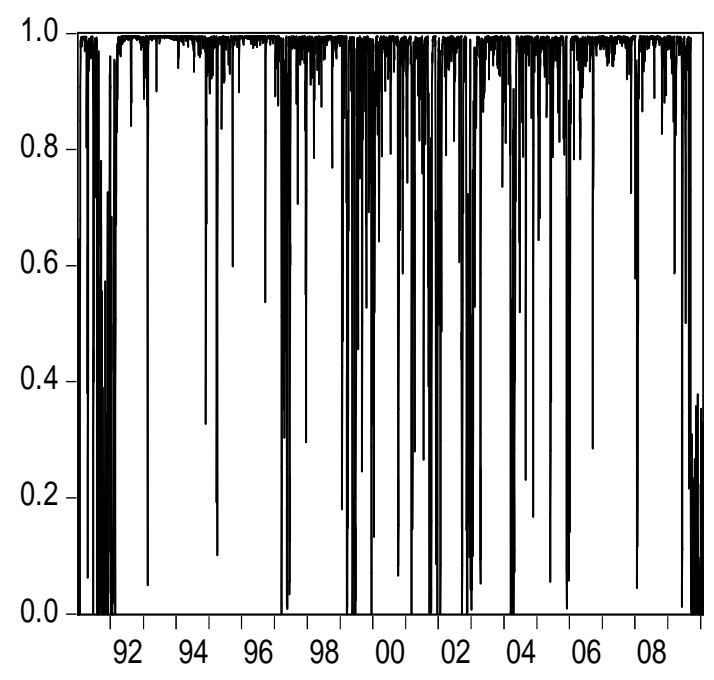

REGIME PROBABILITY

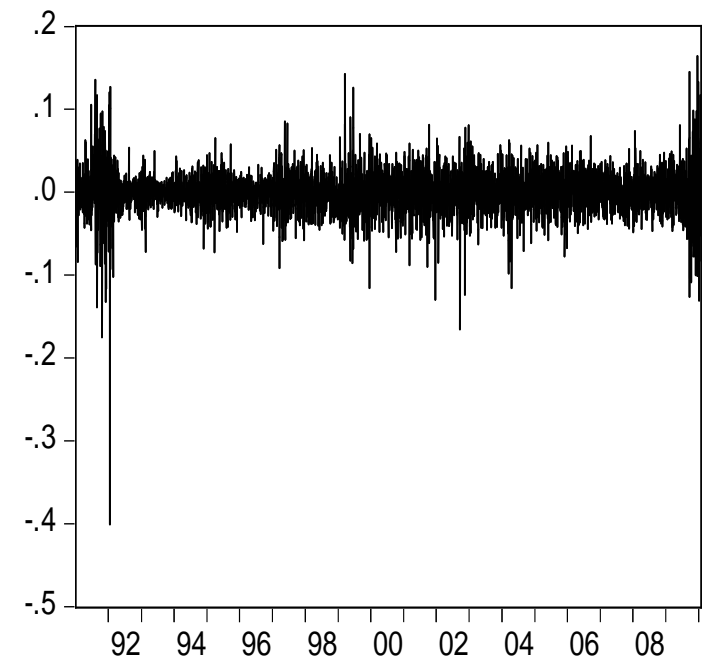

OIL FUTURES DAILY RATE OF RETURN

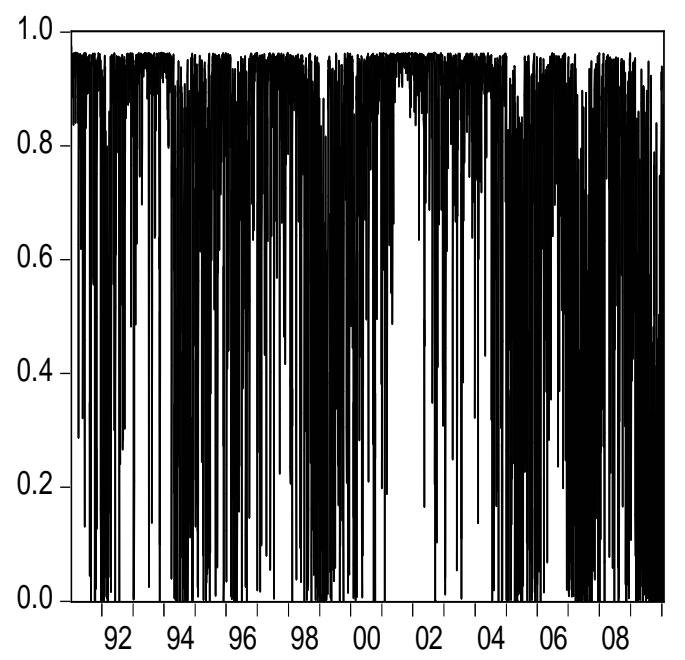

REGIME PROBABILITY

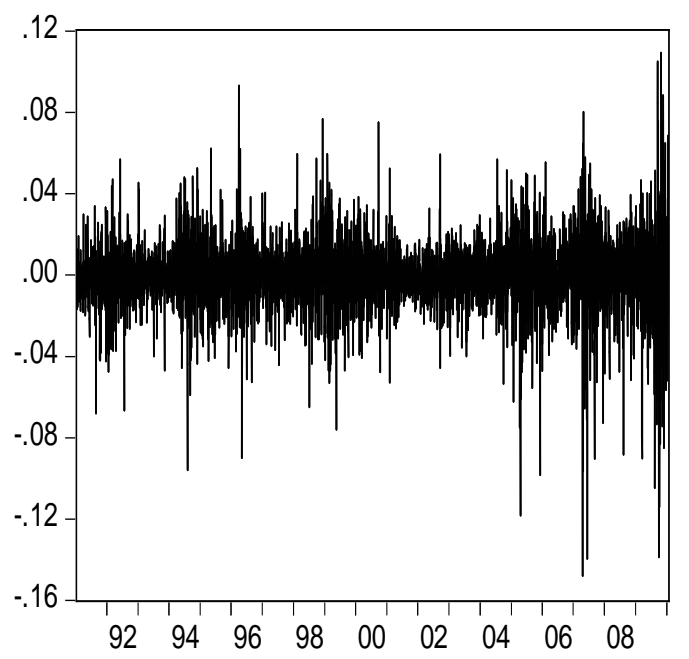

SILVER FUTURES DAILY RATE OF RETURN 
FIGURE 3
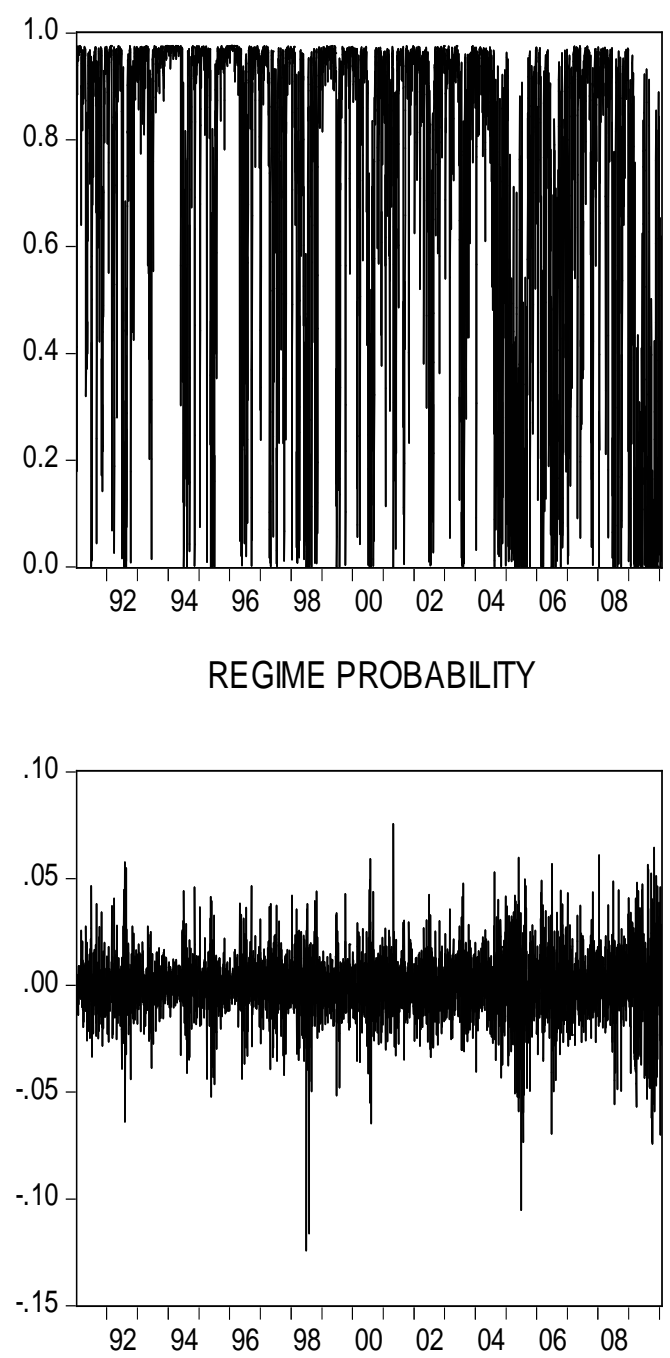

SOYABEANS FUTURES DAILY RATE OF RETURN 


\section{References}

Achen C. Interpreting and Using Regression. Thousand Oaks, CA: Sage Publications. (1982)

Ai, C., A. Chatrath, and F. Song. "On the Comovement of Commodity Prices". American Journal of Agricultural Economics 88 (2006): 574-588.

Alexander, C., and A. Barbosa. "Effectiveness of Minimum Variance Hedging". Journal of Portfolio Management 33 (2007): 46-59.

Alizadeh, A., and N. Nomikos. "A Markov Regime Switching Approach for Hedging Stock Indices". Journal of Futures Markets 24 (2004): 649-674.

Baillie, R., and R. Myers. "Bivariate GARCH Estimation of the Optimal Commodity Futures Hedge". Journal of Applied Econometrics 6 (1991): 109-124.

Benninga, S., R. Eldor, and I. Zilcha. "Optimal Hedging in the Futures Market Under Price Uncertainty". Economics Letters 13 (1983): 141-145.

Bessembinder, H. "Systematic Risk, Hedging Pressure and Risk Premiums in Futures Markets". Review of Financial Studies 5 (1992): 637-667.

Bollerslev T., and J.M. Wooldridge. "Quasi-maximum Likelihood Estimation and Inference in Dynamic Models with Time-varying Covariances". Econometric Reviews 11 (1992): 143-172.

Cashin, P., McDermott, C.J. and A. Scott. "The Myth of Comoving Commodity Prices." IMF Working Paper 169 (1999).

Cecchetti, S.G., Cumby, R.E., and S. Figlewski. "Estimation of the Optimal Futures Hedge". Review of Economics and Statistics 70 (1988): 623-630.

Chan, W., and D. Young. "Jumping Hedges: An Examination of Movements in Copper Spot and Futures Markets". Journal of Futures Markets, 26 (2006): 169-188.

Chang, B. "Returns to Speculators and the Theory of Normal Backwardation". Journal of Finance 40 (1985): 193-208.

Chen, S.S., Lee, C.F., and K. Shrestha. "Do Pure Martingale and Joint Normality Hypothesis Hold for Futures Contracts? Implication for the Optimal Hedge Ratios". Quarterly Review of Economics and Finance 48 (2008): 153-174.

Ederington, L.H. "The Hedging Performance of the New Futures Markets". Journal of Finance 34 (1979): 157 - 170.

Fagan, S., and R. Gencay. "Liquidity-Induced Dynamics in Futures Markets". MPRA Working Paper 6677 January (2008). 
Figlewski, S. "Hedging Performance and Basis Risk in Stock Index Futures". Journal of Finance 39 (1984): 657-669.

Garbade, K.D., and W.L. Silber. "Price Movements and Price Discovery in Futures and Cash Markets". Review of Economics and Statistics 65 (1983): 289-297.

Hamilton, J.D. "A New Approach to the Economic Analysis of Nonstationary Time Series and the Business Cycle". Econometrica 57 (1989): 357-384.

Hamilton, J.D. Time series analysis. Princeton, NJ: Princeton University Press. (1994).

Hieronymus, T.A. Economics of Futures Trading for Commercial and Personal Profit. $2^{\text {nd }}$ reprint New York: Commodity Research Bureau Inc. (1977)

Irwin, S.H., Sanders, D.R., and R.P. Merrin. "Devil or Angel? The Role of Speculation in the Recent Commodity Price Boom (and Bust)". Journal of Agricultural and Applied Economics 41 (2009): 377-391.

Johnson, L.L. "The theory of Hedging and Speculation in Commodity Futures". Review of Economic Studies 27 (1960): 139-151.

Kavussanos, M.C., and I.D. Visvikis. "Hedging Effectiveness of the Athens Stock Index Futures Contracts". European Journal of Finance 14 (2008): 243-270.

Kolb, R.W., and J. Okunev. 'An Empirical Evaluation of the Extended Mean-Gini Coefficient for Futures Hedging', Journal of Futures Markets 12 (1992): 177-186.

Kroner, K.F., and J. Sultan. "Time-varying Distribution and Dynamic Hedging with Foreign Currency Futures". Journal of Financial and Quantitative Analysis 28 (1993): 535-551.

Lee, T.H., and J. Yoder. "Optimal Hedging With a Regime-Switching TimeVarying Correlation Garch Model". Journal of Futures Markets 27 (2007): 495-516.

Lence, S.H. "The Economic Value of Minimum-Variance Hedges". American Journal of Agricultural Economics 77 (1995): 353-364.

Le Pen, Y., and B. Sévi. "Revisiting the Excess Co-movements of Commodity Prices in a Data-Rich Environment" memo Université de Nantes (2010).

Lescaroux, F. "On the Excess Co-movement of Commodity Prices-A Note about the Role of Fundamental Factors in Short-Run Dynamics". Energy Policy 37 (2009): 3906-3913. 
Lien, D. "A Note on the Hedging Effectiveness of GARCH Models". International Review of Economics and Finance 18 (2009): 110-112.

Lien, D. and Y.K. Tse. "Hedging Downside Risk with Future Contracts". Applied Financial Economics 10 (2000):163-170.

McKinnon, R.L. "Futures Markets, Buffer Stocks and Income Stability for Primary Producers". Journal of Political Economy 73 (1967): 844-861.

Miffre, J." Conditional OLS Minimum Variance Hedge Ratios". Journal of Futures Markets 24 (2004): 945-964.

Park, S.Y., and S.Y. Jei. " Estimation and Hedging Effectiveness of TimeVarying Hedge Ratio: Flexible Bivariate Garch Approaches". Journal of Futures Markets 30 (2010): 71-99.

Pyndick, R.S., and J.J. Rotemberg. "The Excess Co-movement of Commodity Prices". Economic Journal 100 (1990): 1173-1189.

Sarno, L., and G. Valente. "The Cost of Carry Model and Regime Shifts in Stock Index Futures Markets: An Empirical Investigation". Journal of Futures Markets 20 (2000): 603-624.

Stein, J.L. " The Simultaneous Determination of Spot and Futures Prices". American Economic Review 51(1961): 1012-1025.

Stulz, R.M. "Rethinking Risk Management". Journal of Applied Corporate Finance 9 (1996): 8-24.

Ward, R.W., and L.B. Fletcher. "From Hedging to Pure Speculation: a Micro Model of Futures and Cash Market Positions". American Journal of Agricultural Economics 53 (1971): 71-78. 